\title{
A Highly Efficient Method for Synthesis of Bisarylmethylidenes of Cyclic Ketones in [BMIm] Cl/NaOH System as New and Recyclable Catalyst
}

\author{
Shahrzad Javanshir ${ }^{a^{*}}$, Mohammad M. Mojtahedi ${ }^{\mathrm{b}}$ and Javad Eslami ${ }^{\mathrm{a}}$
}

${ }^{a}$ College of Chemistry, Iran University of Science and Technology, Tehran 16846-13114, Iran

${ }^{b}$ Chemistry and Chemical Engineering Research Center of Iran, P.O. Box 14335-186, Tehran, Iran

C H R ON I C L E A B T R A C T

Article history:

Received June 28, 2013

Received in Revised form

December 10, 2013

Accepted 10 February 2014

Available online

14 February 2014

Keywords:

Ionic Liquid

Aldol Condensations

Bisarylmethylidenes

Chalcones

\begin{abstract}
An ionic liquid 1-Butyl-3-methylimidazoliumchloride[BMIm] Cl/sodium hydroxide system, was employed as a catalyst for the fast and one-pot crossed aldol-condensation of various aromatic aldehydes and cyclic ketones, to produce a variety of substituted $\alpha, \alpha^{\prime}$-bis(benzylidene)cycloalkanones under neat conditions. This process is simple, efficient and environmentally benign and proceeds in high yield and short reaction times. The ionic liquid can be recycled for subsequent reactions without any appreciable loss of efficiency.
\end{abstract}

\section{Introduction}

The aldol condensation and related reactions have been widely applied for carbon-carbon bond formation in organic synthesis. Among them, the Claisen-Schmidt condensation of aryl aldehydes with cycloalkanones is an important reaction for the preparation of $\alpha, \alpha^{\prime}$-bis(arylidene)cycloalkanones. These arylidene derivatives are intermediates of various pharmaceuticals whit intriguing biological activities such as antibacterial and antifungal ${ }^{1}$, antitubercular ${ }^{2}$, cytotoxicity ${ }^{3}$, antioxidant ${ }^{4}$, antiinflammatory $^{4 \mathrm{~b}, 5}$, antianiogenic ${ }^{6}$, HIV-1 integrase inhibitory ${ }^{7}$, analgesic ${ }^{4 \mathrm{~b}, 5 \mathrm{~b}, 8}$, antiparkinsonian and anticonvulsant $^{8}$. Moreover, they are used as precursor for agrochemical and perfumes ${ }^{9}$, new organic material for nonlinear optical applications ${ }^{10}$, the units of liquid crystalline polymers ${ }^{11}$, and enantioselective catalysts in the synthesis of medicinally relevant compounds ${ }^{12}$.

Usually this type of condensation has been catalyzed by bases and occasionally by strong acids. Nevertheless, in such harsh conditions, the reactions suffer from reverse and/or side reactions and 
may give the corresponding products in low yields ${ }^{13}$. Subsequently, improved by utilization of gentle catalysts methodologies have been reported. The most successful catalyst used there was: different organometallic complexes ${ }^{14}, \mathrm{Rh}$ (III) porphyrine ${ }^{15}, \mathrm{RuCl}_{3}{ }^{16}, \mathrm{SmI}_{3}{ }^{17}, \mathrm{BF}_{3} . \mathrm{Et}_{2} \mathrm{O}^{18}, \mathrm{FeCl}_{3} \cdot 6 \mathrm{H}_{2} \mathrm{O}^{19}$, $\mathrm{ZnBr}_{2} / \mathrm{Et}_{3} \mathrm{~N}^{20}, \mathrm{Mg}\left(\mathrm{HSO}_{4}\right)_{2}{ }^{21}, \mathrm{Pd} / \mathrm{C}-(\mathrm{TMSCl}){ }^{22}, \mathrm{LiClO}_{4}{ }^{23}, \mathrm{Yb}(\mathrm{OTf})_{3}{ }^{24}$, rare earth(III) perfluorooctane sulfonates ${ }^{25}, \quad \mathrm{InCl}_{3} .4 \mathrm{H}_{2} \mathrm{O}^{26}, \mathrm{Cu}(\mathrm{OTf})_{2}{ }^{27}, \mathrm{Cp}_{2} \mathrm{ZrH}_{2}$ and $\mathrm{Cp}_{2} \mathrm{Zr}(\mathrm{O}-\mathrm{i}-\mathrm{Pr})_{2}{ }^{28}$, lithium iodide ${ }^{29}$, $\mathrm{CH}_{3} \mathrm{CO}_{2} \mathrm{Na} / \mathrm{CH}_{3} \mathrm{CO}_{2} \mathrm{H}^{30}$, the micellar medium ${ }^{31}$, polymer-supported sulfonic acid (NKC-9) ${ }^{32}$, $\mathrm{SOCl}_{2} / \mathrm{EtOH}^{33}, \mathrm{TiCl}_{3}\left(\mathrm{SO}_{3} \mathrm{CF}_{3}\right)^{34}, \mathrm{Ti}(\mathrm{OR})_{4}{ }^{35}$ etc. However, in the most cases, process suffers from high cost and difficult catalyst preparation, uses of toxic or stoichiometric amounts of catalyst, hydrolyzing of catalyst in the presence of water which may result in the aldol-condensation reactions, not recyclability of that catalysts, long reaction time or high reaction temperature, unwanted side reactions, involving complicated or tedious purification operations, generation of large amount of wastes, low yields and peculiar reaction conditions. Therefore, because of the importance for the preparation of $\alpha, \alpha^{\prime}$-bis(arylidene)cycloalkanones, it is important to exploit a simple, efficient, and clean procedure for cross-condensation from the views of environmental and green chemistry.

During the past decade, room temperature ionic liquids (RT ILs), have attracted considerable attention due to their special characteristics including high thermal and chemical stability, excellent solubility with organic and inorganic compounds, electrochemical properties, non-flammability, ease of handling and recycling, wide liquid range and negligible vapor pressure. These striking properties allow them to be applied as catalyst and dangerous organic solvent substitutes. Ionic liquids are usually formed by a bulky aromatic organic cation and an inorganic anion. By chemically modifying these two species, ILs can be prepared in large varieties with different, tailor-made properties. Because of all above, ILs have attracted an increasing attention and used in many different applications (chemistry, biochemistry, electrochemistry, or engineering) which is shown in the exponential grown of publications related to these materials ${ }^{36}$.

Utilization of ionic liquids as catalytic promoter is an important topic in organic synthesis. Following our recent studies on programs aimed at greener chemistry ${ }^{37}$ we wish to report an efficient, convenient and facile method for the condensation of aldehydes (1) with cycloalkanones (2) leading to the corresponding $\alpha, \alpha^{\prime}$-bis(substitutedbenzylidene)cycloalkanones (3) promoted by ionic liquid $[\mathrm{BMIm}][\mathrm{Cl}] / \mathrm{NaOH}$ system (scheme 1 ).

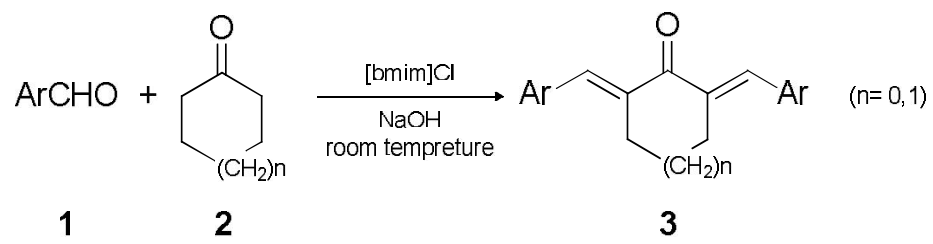

Scheme 1. Cross-aldol condensation based synthesis of $\alpha, \alpha^{\prime}$-bis(benzylidene)cycloalkanones

\section{Results and Discussion}

Initially, we aimed to examine the possibility of aldol condensation in the presence of [BMIm] OH as a basic ionoic liquid, hence we tried to synthesis [BMIm] OH according to the procedure published by Ranu et $\mathrm{al}^{38}$. Surprisingly, we couldn't obtain the desired ionic liquid in pure and stable form. Same result had been observed by Chen et $\mathrm{al}^{39}$. They have founded that [BMIm]OH decomposes rapidly in drying step, but it is moderately stable when a small water content is maintained. These observations led us to in situ generation of [BMIm] $\mathrm{OH}$ in aqueous media during the aldol condensation. But before this, we performed a set of experiments to determine and optimize the reaction conditions with several other reagents.

We first chose the reaction of benzaldehyde $(2 \mathrm{mmol})$ and cyclohexanone $(1 \mathrm{mmol})$ and several ionic liquids (0.5 mmol) such as 1-butyl-3-methylimidazolium chloride [BMIm]Cl, 1-butyl-3- 
methylimidazolium bromide $[\mathrm{BMIm}] \mathrm{Br}$, 1-butyl-3-methylimidazolium hexafluorophophate [BMIm] $\mathrm{PF}_{6}$ and 1-butyl-3-methylimidazolium tetrafluoroborate $\left[\mathrm{BMIm}^{-} \mathrm{BF}_{4}\right.$ as a model reaction in water $(0.5 \mathrm{ml})$ at ambient temperature. After being stirred for several hours $(24 \mathrm{~h})$, the reactants kept unchanged. Increasing temperature had no effect on the course of the reaction.

Based on these results, we then performed the cross-aldol condensation using these ILs in the presence of a base. Interestingly, when $\mathrm{NaOH}$ was used as base the corresponding $\alpha, \alpha^{\prime}$-bis (benzylidene) cyclohexanone was obtained in good to moderate yields (Table 1).

Table 1. Preparation of $\alpha, \alpha^{\prime}$-bis(benzylidene)cyclohexanone in several ionic liquids ${ }^{a}$.

\begin{tabular}{cccc}
\hline Entry & Ionic liquid & Time $(\mathrm{h})$ & Yield $(\%)$ \\
\hline 1 & {$[\mathrm{BMIm}] \mathrm{Cl}$} & 2 & 88 \\
2 & {$[\mathrm{BMIm}] \mathrm{Br}$} & 3 & 85 \\
3 & {$[\mathrm{BMIm}] \mathrm{PF}_{6}$} & 3 & 43 \\
4 & {$\left[{\mathrm{BMIm}] \mathrm{BF}_{4}}\right.$} & 6 & 56 \\
\hline
\end{tabular}

${ }^{a}$ Reaction conditions: $1 \mathrm{mmol}$ ionic liquid, $2 \mathrm{mmol}$ benzaldehyde, $1 \mathrm{mmol}$ cyclohexanone, $1 \mathrm{mmol} \mathrm{NaOH}, 0.5 \mathrm{ml}$ water, room temperature.

As can be seen from Table 1, [BMIm]Cl is the suitable choice for an optimum yield. In the next step, a set of experiments were performed to find out the appropriate amount of [BMIm]Cl for this reaction. The results were summarized in Table 2. Best result was obtained when $0.5 \mathrm{mmol}$ of this ionic liquid was used. Excessive amounts of catalyst cannot greatly increase the yields.

Table 2. Effect of the [BMIm]Cl amount on the preparation of $\alpha, \alpha^{\prime}$-bis(benzylidene)cyclohexanone ${ }^{\text {a }}$

\begin{tabular}{ccc}
\hline Entry & {$[\mathrm{BMIm}] \mathrm{Cl}(\mathrm{mmol})$} & Yield $(\%)$ \\
\hline 1 & 0.2 & 60 \\
2 & 0.5 & 85 \\
3 & 1 & 88 \\
\hline
\end{tabular}

${ }^{a}$ Reaction conditions: $2 \mathrm{mmol}$ benzaldehyde, $1 \mathrm{mmol}$ cyclohexanone, $1 \mathrm{mmol} \mathrm{NaOH}, 0.5 \mathrm{ml}$ water, room temperature.

In order to study the effect of base type and nature, parallel experiments were carried out using some other organic and inorganic bases (Table 3). As illustrated in Table 3, best results were obtained when Inorganic bases were used. Among organic bases DABCO showed only $45 \%$ yield in 48 hours while $\mathrm{NaOH}$ gave the yield almost twofold in 2 hours.

Table 3. Effect of base nature on the preparation of $\alpha, \alpha^{\prime}$-bis(benzylidene)cyclohexanone ${ }^{\text {a }}$

\begin{tabular}{cccc}
\hline Entry & base & Time $(\mathrm{h})$ & Yield (\%) \\
\hline 1 & $\mathrm{DABCO}$ & 48 & 45 \\
2 & Pyrrolidine & 48 & trace \\
3 & $\mathrm{Et}_{3} \mathrm{~N}$ & 48 & 20 \\
4 & $\mathrm{~K}_{2} \mathrm{CO}_{3}$ & 48 & 35 \\
5 & $\mathrm{NaHCO}_{3}$ & 48 & trace \\
6 & $\mathrm{KOH}$ & 2 & 87 \\
7 & $\mathrm{NaOH}$ & 2 & 88 \\
\hline
\end{tabular}

${ }^{a}$ Reaction conditions: $1 \mathrm{mmol}$ base, $0.5 \mathrm{mmol}$ [BMIm]Cl, $2 \mathrm{mmol}$ benzaldehyde, $1 \mathrm{mmol}$ cyclopentanone, room temperature

Furthermore, the amount of $\mathrm{NaOH}$ in the system was optimized (Table 4).

Table 4. Effect of the $\mathrm{NaOH}$ amount on the preparation of $\alpha, \alpha^{\prime}$-bis(benzylidene)cyclohexanone ${ }^{\mathrm{a}}$

\begin{tabular}{ccc}
\hline Entry & $\mathrm{NaOH}(\mathrm{mmol})$ & Yield $(\%)$ \\
\hline 1 & 0.2 & 25 \\
2 & 0.5 & 62 \\
3 & 0.75 & 85 \\
4 & 1 & 87 \\
\hline
\end{tabular}

${ }^{a}$ Reaction conditions: $0.5 \mathrm{mmol}$ [BMIm]Cl, 2 mmol benzaldehyde, $1 \mathrm{mmol}$ cyclopentanone, 2 hours, room temperature 
According to obtained results, we conclude that $0.5 \mathrm{mmol}(0.084 \mathrm{~g})[\mathrm{BMIm}] \mathrm{Cl}$ and $0.75 \mathrm{mmol}$ $(0.03 \mathrm{~g}) \mathrm{NaOH}$ are sufficient for satisfactory results. To evaluate the reaction scope and generality of the catalytic system, the reactions of cyclopentanone and cyclohexanone with several aromatic aldehydes were conducted. The results were summarized in Table 5. The aromatic aldehydes with electron-donating substitutions (entries 4 and 5, Table 5) reacted smoothly with cyclohexanone and cyclopentanone as well as electron-withdrawing groups (entries 2 and 3 Table 5) to afford the corresponding $\alpha, \alpha^{\prime}$-bis(substituted benzylidene) cycloalkanones in good to excellent yields.

Comparison of the results revealed that the reaction of cyclopentanone with a particular aldehyde (Table 5, entries $1-6, n=0$ ) was faster than that of cyclohexanone with the same aldehyde (Table 5, entries 1-6, $\mathrm{n}=1$ ). This may be due to the removal of the eclipsing effect of the adjacent hydrogen atoms in cyclopentanone after the formation of the arylmethylidene derivative. In addition, aldehydes with electron donating substituent required longer times due to the decrease in electrophilicity of the aldehyde carbonyl carbon, compared to substrates devoid of such substituents (compare entry 2 and 3 with entries 4 and 5, Table 5). Heterocyclic aldehydes react smoothly under the same conditions but in a higher yield (entries 7-8). The melting points of the synthesized compounds are in agreement with the values reported in the literature (Table 5).

Moreover, using [BMIm] $\mathrm{Cl} / \mathrm{NaOH} /$ water system as the catalyst and reaction medium also made the separation process much easier. For example, with this system, the product can be obtained with high purity through simple filtration and rinsing of the filtrates with a little amount of water. Whereas, some other methods reported in literature suffer from harsh workup procedure.

Table 5. Condensation of various aromatic aldehydes with cyclic Ketones ${ }^{\text {a }}$

\begin{tabular}{|c|c|c|c|c|c|}
\hline Entry & Aldehyde & Product & M.p $\left({ }^{\circ} \mathrm{C}\right)\left(\right.$ reported $\left.^{1}\right)$ & Yield (\%) & Time $/ \mathrm{min}$ \\
\hline 1 & & & $\begin{aligned} \mathbf{5 a}: \mathrm{n} & =0: 187-188(188-189) \\
\mathbf{5 i}: \mathrm{n} & =1: 114-115(116-117)\end{aligned}$ & $\begin{array}{l}90 \\
85\end{array}$ & $\begin{array}{c}60 \\
120\end{array}$ \\
\hline 2 & & & $\begin{array}{l}\mathbf{5 b}: \mathrm{n}=0: 224-226(227-228) \\
\mathbf{5 j}: \mathrm{n}=1: 145-146(144-145)\end{array}$ & $\begin{array}{l}92 \\
94\end{array}$ & $\begin{array}{l}15 \\
45\end{array}$ \\
\hline 3 & & & $\begin{array}{l}\mathbf{5 c}: \mathrm{n}=0: 239-240(237-239) \\
\mathbf{5 k}: \mathrm{n}=1: 154-155(157-159)\end{array}$ & $\begin{array}{l}94 \\
95\end{array}$ & $\begin{array}{l}10 \\
70\end{array}$ \\
\hline 4 & & & $\begin{array}{l}\text { 5d: } \mathrm{n}=0: 240-241(244-245) \\
\text { 5l: } \mathrm{n}=1: 165-166(163-164)\end{array}$ & $\begin{array}{l}87 \\
88\end{array}$ & $\begin{array}{l}45 \\
150\end{array}$ \\
\hline 5 & & & $\begin{array}{l}\text { 5e: } \mathrm{n}=0: 211-212(211-212) \\
\mathbf{5 m}: \mathrm{n}=1: 159-160(161-163)\end{array}$ & $\begin{array}{l}89 \\
84\end{array}$ & $\begin{array}{c}30 \\
180\end{array}$ \\
\hline 6 & & & $\begin{array}{l}\text { 5f: } n=0: 280-282 \\
\text { 5n: } n=1: 196-198\end{array}$ & $\begin{array}{l}86 \\
63\end{array}$ & $\begin{array}{c}45 \\
240\end{array}$ \\
\hline 7 & & & $\begin{array}{l}\text { 5g: } n=0: 174-175(176-178) \\
\text { 50: } n=1: 140-142(142-143)\end{array}$ & $\begin{array}{l}95 \\
96\end{array}$ & $\begin{array}{l}60 \\
60\end{array}$ \\
\hline 8 & & & $\begin{array}{l}\mathbf{5 h}: \mathrm{n}=0: 161-162(163-164) \\
\mathbf{5 p}: \mathrm{n}=1: 144-145(145-146)\end{array}$ & $\begin{array}{l}96 \\
95\end{array}$ & $\begin{array}{l}60 \\
60\end{array}$ \\
\hline
\end{tabular}

${ }^{a}$ Reaction conditions: $2 \mathrm{mmol}$ aldehyde, $1 \mathrm{mmol}$ Ketone, $0.5 \mathrm{mmol}$ [BMIm] Cl, $0.75 \mathrm{mmol} \mathrm{NaOH}, 0.5 \mathrm{ml}$ water, room temperature 
Next, we also investigated the reusability and the recycling of the ionic liquid [BMIm]Cl, and founded that the catalyst could be easily recovered after completion of the reaction and reused in subsequent reactions. The reaction of benzaldehyde with cyclohexanone at room temperature as a model reaction was again studied. After completion of the reaction, small amount of water was added to the reaction mixture. The solid precipitate was isolated by filtration and washed with $3 \times 5 \mathrm{ml}$ water. The ionic liquid left in the filtrate was dried under vacuum and reused for again for fresh reaction. The activity of the catalyst did not show any significant decrease after 4 runs (Table 6).

Table 6. Reusability study of the catalyst in the model reaction

\begin{tabular}{cc}
\hline round & Yield (\%) \\
\hline 1 & 85 \\
2 & 83 \\
3 & 83 \\
4 & 82 \\
\hline
\end{tabular}

\section{Conclusions}

In this paper, we present an efficient and convenient protocol for the synthesis $\alpha, \alpha^{\prime}-$ bis(substituted benzylidene)cycloalkanones via cross-aldol condensation between arylaldehydes and cycloalkanones catalyzed by $[\mathrm{BMIm}] \mathrm{Cl} /$ sodium hydroxide system. The reaction can be carried out in water at room temperature. The main advantages of this method are mild reaction conditions, higher yields, user friendly and green procedure, shorter reaction period and the possibility of catalyst reuse.

\section{Acknowledgements}

We are grateful for the financial support from Research Council of Iran University of Science and Technology (IUST), Iran.

\section{Experimental}

\subsection{Materials and Methods}

The progress of the reaction and the purity of compounds were monitored using Merck $0.2 \mathrm{~mm}$ silica gel 60 F-254 Al-plates. Melting points were determined in capillary tubes on a Barnstead Electro thermal apparatus and are uncorrected. FT-IR spectra were recorded using $\mathrm{KBr}$ disks on an FT-IR SHIMADZU 8400S infrared spectrometer and absorptions were reported as wave numbers $\left(\mathrm{cm}^{-1}\right)$. NMR spectra were obtained on a FTNMR Bruker Ultra ShieldTM (500-MHz) instrument using $\mathrm{CDCl}_{3}$ as solvent and TMS as an internal standard. Mass spectra were obtained on a Finnigan Mat 8430 apparatus at ionization potential of $70 \mathrm{eV}$. Ionic liquids were prepared using available methods. All other reagents were purchased from commercial sources and were freshly used after being purified by standard procedures. All known compounds were identified by comparison of their melting points with authentic samples or reported in the literature and Yields refer to isolated yields.

\subsection{Preparation of 1-butyl-3-methylimidazolium chloride [BMIm]Cl}

The ionic liquids were prepared and purified by using the procedures described in the literature. ${ }^{40}$ Briefly, [BMIm] Cl was synthesized by direct alkylation of $N$-methylimidazole with an excess amount of 1-chlorobutane in a round-bottom flask along with continuous stirring at $\mathrm{T}=80^{\circ} \mathrm{C}$ for $48 \mathrm{~h}$ under a nitrogen atmosphere. The volatile material was removed from the resulting yellow solution under reduced pressure and remaining light-yellow oil was redissolved in dry acetonitrile and added drop wise to a well-stirred solution of dry ethyl acetate. The imidazolium salt began to crystallize exothermically almost immediately. Then the mixture was cooled at $-30^{\circ} \mathrm{C}$ for $2 \mathrm{hr}$ and the 
supernatant solution is removed via filtration and the resulting white solid was dried under reduced pressure. This synthesized ionic liquid was analyzed by ${ }^{1}$ HNMR to confirm the absence of any major impurities, and it was found to be in good agreement with that reported in the literature.

\subsection{General procedure}

In a Pyrex test tube, water $(0.5 \mathrm{ml})$ was added to $[\mathrm{BMIm}] \mathrm{Cl}(0.084 \mathrm{~g}, 0.5 \mathrm{mmol})$ and stirred until a viscous liquid was afforded. Afterward, Ketone $(1 \mathrm{mmol})$, aromatic aldehyde $(2 \mathrm{mmol})$ and $\mathrm{NaOH}$ $(0.03 \mathrm{~g}, 0.75 \mathrm{mmol})$ were added to this solution. The mixture was stirred at room temperature for an appropriate time (Table 5), after completion of the reaction (monitored by TLC), the solid residue was filtered off, washed with water $(3 \times 5 \mathrm{~mL})$, dried at $100{ }^{\circ} \mathrm{C}$ for 24 hours and recrystallized from ethyl acetate or ethanol to afford pure corresponding $\alpha, \alpha^{\prime}$-bis(substituted benzylidene) cycloalkanones.

\subsection{Physical and Spectral Data}

Compound 5f. Yellow solid (86\%). Mp. 282-280 ${ }^{\circ} \mathrm{C} ;{ }^{1} \mathrm{HNMR}\left(500 \mathrm{MHz}, \mathrm{CDCl}_{3}\right): \delta 3.17(\mathrm{~s}, 4 \mathrm{H})$, $3.95(\mathrm{~s}, 6 \mathrm{H}), 7.67(\mathrm{~s}, 2 \mathrm{H}), 9 / 7(\mathrm{~d}, J=8.4 \mathrm{~Hz}, 4 \mathrm{H}), 1 / 8(\mathrm{~d}, J=8.35 \mathrm{~Hz}, 4 \mathrm{H}) .{ }^{13} \mathrm{CNMR}(125 \mathrm{MHz}$, $\left.\mathrm{CDCl}_{3}\right)=26.57,52.26,130.20,130.45,130.54,132.91,139.05,139.07,49.166,27.196 ; \mathrm{MS}(70 \mathrm{eV})$ : $\mathrm{m} / \mathrm{z}(\%)=375\left(\mathrm{M}^{+}\right), 361,345,317,258,129,115$.

Compound 5n. Yellow solid (63\%). Mp. 196-198 ${ }^{\circ} \mathrm{C}$; IR (KBr): 1716، 1272 ،1108 cm cm $^{-1}$ ${ }^{1} \mathrm{HNMR}\left(500 \mathrm{MHz}, \mathrm{CDCl}_{3}\right): \delta 1.8-1.7(\mathrm{~m}, 2 \mathrm{H}), 2.9(\mathrm{~m}, 2 \mathrm{H}), 3.9(\mathrm{~s}, 6 \mathrm{H}), 7.5(\mathrm{~d}, J=8.2 \mathrm{~Hz}, 4 \mathrm{H}), 7.8$ $(\mathrm{s}, 2 \mathrm{H}), 8.0(\mathrm{~d}, J=8,3 \mathrm{~Hz}, 4 \mathrm{H}) ;{ }^{13} \mathrm{CNMR}\left(125 \mathrm{MHz}, \mathrm{CDCl}_{3}\right): \delta 22.72,28.39,52.17,126.55,126.85$, 130.07, 135.91, 137.64, 140.26, 166.56, 189. 77; MS (70 eV ): m/z(\%) = 389( $\left.\mathrm{M}^{+}\right), 375,359,331$, $272,115$.

\section{References}

1. Arsanious, M. H. N.; El-Din, N. K.; Boulos, L. S. (2009) Synthesis of new benzoxaphosphole derivatives from the reaction of dialkylphosphonates and trisdialkylaminophosphines with 2,6bis(benzylidene)cyclohexanones. Phosphorus, Sulfur Silicon Relat. Elem., 184, 2813-2826.

2. (a) Kumar, R. R.; Loganayaki, B.; Perumal, S. (2009) Sequential 1,3-dipolar cycloadditions in the synthesis of novel tri-spiro cyclohexanones and piperidin-4-ones. Synth. Commun., 39, 3197 - 3216; (b) Singh, N.; Pandey, J.; Yadav, A.; Chaturvedi, V.; Bhatnagar, S.; Gaikwad, A. N.; Sinha, S. K.; Kumar, A.; Shukla, P. K.; Tripathi, R. P. (2009) A facile synthesis of $\alpha, \alpha^{\prime}-(\mathrm{E}, \mathrm{E})$-bis(benzylidene)-cycloalkanones and their antitubercular evaluations. Eur. J. Med. Chem., 44, 1705-1709.

3. (a) Modzelewska, A.; Pettit, C.; Achanta, G.; Davidson, N. E.; Huang, P.; Khan, S. R. (2006) Anticancer activities of novel chalcone and bis-chalcone derivatives. Bioorg. Med. Chem., 14, 3491-3495; (b) Dimmock, J. R.; Kumar, P.; Nazarali, A. J.; Motaganahalli, N. L.; Kowalchuk, T. P.; Beazely, M. A.; Wilson Quail, J.; Oloo, E. O.; Allen, T. M.; Szydlowski, J.; DeClercq, E.; Balzarini, J. (2000) Cytotoxic 2,6-bis(arylidene)cyclohexanones and related compounds. Eur. J. Med. Chem., 35, 967-977; (c) Dimmock, J. R.; Das, U.; Gul, H. I.; Kawase, M.; Sakagami, H.; Baráth, Z.; Ocsovsky, I.; Molnár, J. (2005) 3Arylidene-1-(4-nitrophenylmethylene)-3,4-dihydro-1H-naphthalen-2-ones and related compounds displaying selective toxicity and reversal of multidrug resistance in neoplastic cells. Bioorg. Med. Chem. Lett., 15, 1633-1636; (d) Ciufolini, M. A.; Byrne, N. E. (1991) The total synthesis of cystodytins. J. Am. Chem. Soc., 113, 8016-8024; (e) Dimmock, J. R. A.; Padmanilayam, M. P.; Zello, G. A.; Nienaber, K. H.; Allen, T. M.; Santos, C. L.; De Clercq, E.; Balzarini, J.; Manavathu, E. K.; Stables, J. P. (2003) Eur. J. Med. Chem., 38, 169; (f) Dimmock, J. R.; Padmanilayam, M. P.; Zello, G. A.; Nienaber, K. H.; Allen, T. M.; Santos, C. L.; De Clercq, E.; Balzarini, J.; Manavathu, E. K.; Stables, J. P. (2003) Cytotoxic analogues of 2,6-bis(arylidene)cyclohexanones. Eur. J. Med. Chem., 38, 169-177.

4. (a) Weber, W. M.; Hunsaker, L. A.; Abcouwer, S. F.; Deck, L. M.; Vander Jagt, D. L. (2005) Anti-oxidant activities of curcumin and related enones. Bioorg. Med. Chem. , 13, 3811-3820; (b) El-Gazzar, A. B. A.; Hafez, H. N.; Nawwar, G. A. M. (2009) New acyclic nucleosides analogues as potential analgesic, anti- 
inflammatory, anti-oxidant and anti-microbial derived from pyrimido[4,5-b]quinolines. Eur. J. Med. Chem., 44, 1427-1436.

5. (a) Nasr, M. N. A.; Said, S. A. (2003) Novel 3,3a,4,5,6,7-Hexahydroindazole and arylthiazolylpyrazoline derivatives as anti-inflammatory agents. Arch. Pharm. ，336, 551-559; (b) Abu-Hashem, A. A.; Gouda, M. A.; Badria, F. A. (2010) Synthesis of some new pyrimido[2',1':2,3]thiazolo[4,5-b]quinoxaline derivatives as anti-inflammatory and analgesic agents. Eur. J. Med. Chem., 45, 1976-1981; (c)

Rovnyak, G.; Shu, V.; Schwartz, J. (1981) Tricyclic thiazolo[3,2-a]thiapyrano[4,3-d]pyrimidines and related analogs as potential anti-inflammatory agents. J. Heterocycl. Chem., 18, 327-331.

6. (a) Robinson, T. P.; Ehlers, T.; Hubbard, I. V. R. B.; Bai, X.; Arbiser, J. L.; Goldsmith, D. J.; Bowen, J. P. (2003) Design, synthesis, and biological evaluation of angiogenesis inhibitors: aromatic enone and dienone analogues of curcumin. Bioorg. Med. Chem. Lett., 13, 115-117; (b) Robinson, T. P.; Hubbard Iv, R. B.; Ehlers, T. J.; Arbiser, J. L.; Goldsmith, D. J.; Bowen, J. P. (2005) Synthesis and biological evaluation of aromatic enones related to curcumin. Bioorg. Med. Chem. , 13, 4007-4013.

7. (a) Artico, M.; Di Santo, R.; Costi, R.; Novellino, E.; Greco, G.; Massa, S.; Tramontano, E.; Marongiu, M. E.; De Montis, A.; La Colla, P. (1998). Geometrically and conformationally restrained cinnamoyl compounds as inhibitors of HIV-1 Integrase: synthesis, biological evaluation, and Molecular Modeling. J. Med. Chem., 41, 3948-3960; (b) Costi, R.; Santo, R. D.; Artico, M.; Massa, S.; Rango, R.; Laddo, R.; Colla, M. L.; Tramontano, E.; Colla, P. L.; Pani, A. (2004) 2,6-Bis(3,4,5-trihydroxybenzylydene) derivatives of cyclohexanone: novel potent HIV-1 integrase inhibitors that prevent HIV-1 multiplication in cell-based assays. Bioorg. Med. Chem, 12, 199.

8. Amr, A. E.-G. E.; Sayed, H. H.; Abdulla, M. M. (2005) Synthesis and reactions of some new substituted pyridine and pyrimidine derivatives as analgesic, anticonvulsant and antiparkinsonian agents. Arch. Pharm., 338, 433-440.

9. Ogawa, M.; Ishii, Y.; Nakano, T.; Irifune, S. (1988) Jpn. Kohai Tokkyo JP 63192446 A2 ; Chem. Abstr. 63 (1988) 238034.

10. Kawamata, J.; Inoue, K.; Inabe, T.; Kiguchi, M.; Kato, M.; Taniguchi, Y. (1996). Large second-harmonic generation coefficients of bis(benzylidine) cycloalkanones estimated by the second-harmonic wave generated with the evanescent wave technique. Chem. Phys. Lett., 249, 29-34.

11. Gangadhara; Kishore, K. (1995) Synthesis and characterization of photo-crosslinkable main-chain liquidcrystalline polymers containing bis(benzylidene)cycloalkanone units. Polym. Int., 36, 1903-1910.

12. Shibuguchi, T.; Mihara, H.; Kuramochi, A.; Sakuraba, S.; Ohshima, T.; Shibasaki, M. (2006). Short synthesis of $(+)$-cylindricine $\mathrm{C}$ by using a catalytic asymmetric michael reaction with a two-center organocatalyst. Angew. Chem. Int. Ed., 45, 4635-4637.

13. Amr, A. E.-G. E.; Sayed, H. H.; Abdulla, M. M. (2005) Synthesis and Reactions of Some New Substituted Pyridine and Pyrimidine Derivatives as Analgesic, Anticonvulsant and Antiparkinsonian Agents. Archiv der Pharmazie, 338, 433-440.

14. Hathaway, B. A. (1987) An aldol condensation experiment using a number of aldehydes and ketones. $J$. Chem. Educ., 64, 367-368.

15. (a) Irie, K.; Watanabe, K. (1980) Bull. Chem. Soc. Jpn., 53, 1366; (b) Nakano, T.; Migita, T. (1993). A convenient synthesis of $\alpha, \alpha$ '-bis(substitutedbenzylidene)cycloalkanones. Chem. Lett., 22, 2157 2158.

16. Oayama, Y.; Tanaka, Y.; Yoshida, Y.; Toi, H.; Ogoshi, H. (1987) Catalytic reactions of metalloporphyrins.: II. Activation and catalytic aldol condensation of ketone with rhodium(III)-porphyrin perchlorate under neutral and mild conditions. J. Organomet. Chem. , 329, 251-266.

17. Iranpoor, N.; Kazemi, F. (1998) RuCI3 catalyses aldol condensations of aldehydes and ketones Tetrahedron, 54, 9475.

18. (a) Bao, W.; Zhang, Y.; Ying, T. (1996) A facile route to synthesize $\alpha, \alpha^{\prime}$-bis(substituted-benzylidene) cycloalkanones promoted by $\mathrm{SmI}_{3}$. Synth. Commun., 26, 503-507; (b) Li, Z.; Zhang, Y.; Li, Q. (2000) Samarium (III) iodide promoted preparation of, $\alpha, \alpha^{\prime}$-bis (substituted benzylidene)cyclohexanones from benzaldehydes and cyclohexanone. J. Chem. Res., Synop., 580-581.

19. Huang, D. F.; Wang, J. X.; Hu, Y. L. (2003) A new solvent-free synthesis of $\alpha, \alpha^{\prime}-$ dibenzylidenecycloalkanones from acetals with cycloalkanones under microwave irradiation. Chin. Chem. Lett., 14, 333.

20. Zhang, X.; Fan, X.; Niu, H.; Wang, J. (2003) An ionic liquid as a recyclable medium for the green preparation of $\alpha, \alpha^{\prime}$-bis (substituted benzylidene)cycloalkanones catalyzed by $\mathrm{FeCl}_{3} .6 \mathrm{H}_{2} \mathrm{O}$. Green Chem., 5 , 267-269. 
21. Abaee, M. S.; Mojtahedi, M. M.; Zahedi, M. M.; Sharifi, R.; Mesbah, A. W.; Massa, W. (2007) Synthesis and structural elucidation of novel bisarylmethylidenes of cyclic enones. Synth. Commun., 37, 2949-2957.

22. Salehi, P.; Khodaei, M. M.; Zolfigol, M. A.; Keyvan, A. (2002) Solvent-free crossed aldol condensation of ketones with aromatic aldehydes mediated by magnesium hydrogensulfate. Monatsh. Chem., 133, 12911295.23.Zhu, Y.; Pan, Y. (2004) A new Lewis acid system palladium/TMSCl for catalytic aldol condensation of aldehydes with ketones. Chem. Lett.

$$
\text { , 33, 668-669. }
$$

23. (a) Abaee, M. S.; Mojtahedi, M. M.; Sharifi, R.; Zahedi, M. M.; Abbasi, H.; Tabar-Heidar, K. (2006) Facile synthesis of bis(arylmethylidene)cycloalkanones mediated by lithium perchlorate under solvent-free conditions. J. Iran Chem. Soc., 3, 293-296; (b) Arnold, A.; Markert, M.; Mahrwald, R. (2006) Amine-catalyzed aldol condensation in the Presence of lithium perchlorate. Synthesis, 7, 1099-1102.

24. Wang, L.; Sheng, J.; Tian, H.; Han, J.; Fan, Z.; Qian, C. (2004) A convenient synthesis of $\alpha, \alpha^{\prime}-$ bis(substituted benzylidene)cycloalkanones catalyzed by $\mathrm{Yb}(\mathrm{OTf})_{3}$ under solvent-free conditions. Synthesis, 18, 3060-3064.

25. Yi, W. B.; Cai, C. (2005) Aldol condensations of aldehydes and ketones catalyzed by rare earth(III) perfluorooctane sulfonates in fluorous solvents. J. Fluorine Chem., 126, 1553-1558.

26. (a) Deng, G.; Ren, T. (2003) Indium trichloride catalyzes Aldol-condensations of aldehydes and ketones. Synth. Commun., 33, 2995-3001; (b) Hu, X.; Fan, X.; Zhang, X.; Wang, J. (2004). $\mathrm{InCl}_{3} \cdot 4 \mathrm{H}_{2} \mathrm{O} / \mathrm{TMSCl}$ catalysed aldol reaction of aromatic aldehydes with cycloalkanones in ionic liquid medium. J. Chem. Res., 684-686.

27. Li, J.; Su, W.; Li, N. (2005) Copper triflate-catalyzed Cross-aldol condensation: a facile synthesis of $\alpha, \alpha^{\prime}-$ bis(substituted benzylidene) cycloalkanones. Synth. Commun., 35, 3037-3043.

28. Nakano, T.; Irfune, S.; Umano, S.; Inada, A.; Ishii, Y.; Ogawa, M. (1987) Cross-condensation reactions of cycloalkanones with aldehydes and primary alcohols under the influence of zirconocene complexes $J$. Org. Chem., 52, 2239- 2244.

29. Kelleher, R. G.; McKervey, M. A.; Vibuljan, P. (1980) Lithium iodide-promoted aldol condensation reactions. J. Chem. Soc., Chem. Commun., 486-488.

30. (a) Zhou, J. F.; Sun, X. J.; Zhu, F. X.; Li, Y. L.; Gong, G.-X. (2008) A facile synthesis of 5-arylidene-2imino-4-thiazolidinones under microwave irradiation. Synth. Commun., 38, 4182-4187; (b) Motiur Rahman, A. F. M.; Jeong, B.-S.; Kim, D. H.; Park, J. K.; Lee, E. S.; Jahng, Y. (2007) A facile synthesis of $\alpha, \alpha^{\prime}$-bis(substituted-benzylidene) cycloalkanones and substituted-benzylidene heteroaromatics: utility of $\mathrm{NaOAc}$ as a catalyst for aldol-type reaction. Tetrahedron, 63, 2426-2431.

31. Shrikhande, J. J.; Gawande, M. B.; Jayaram, R. V. (2008) Cross-aldol and Knoevenagel condensation reactions in aqueous micellar media. Catal. Commun., 9, 1010-1016.

32. An, L. T.; Zou, J. P.; Zhang, L. L. (2008) Polymer-supported sulphonic acid catalyzed cross-aldol condensation: An expeditious synthesis of $\alpha, \alpha^{\prime}$-bis(substituted benzylidene) cycloalkanones. Catal. Commun., 9, 349-354.

33. Hu, Z. G.; Liu, J.; Zeng, P. L.; Dong, Z. B. (2004) Synthesis of $\alpha, \alpha^{\prime}$-bis(substituted benzylidene)ketones catalysed by a $\mathrm{SOCl} / \mathrm{EtOH}$ reagent. J. Chem.Res. 55-56.

34. Iranpoor, N.; Zeynizadeh, B.; Aghapour, A. (1999) Aldol condensation of cycloalkanones with aromatic aldehydes catalysed with $\mathrm{TiCl}_{3}\left(\mathrm{SO}_{3} \mathrm{CF}_{3}\right)$. J. Chem. Res., Synop., 554-555.

35. Mahrwald, R.; Schick, H. (1990) Synthesis of $\alpha, \beta$-unsaturated carbonyl compounds by titanium tetraalkoxide-induced Aldol condensation under neutral conditions. Synthesis, 592-595.

36. (a) Wasserscheid, P.; Welton, T., (2003) Ionic liquids in synthesis. Wiley-VCH: Weinheim,; (b) Leitner, W.; Jessop, P. G.; Li, C.-J.; Wasserscheid, P.; Stark, A., (2010) Handbook of green chemistry. Set II, Green solvents. Wiley-VCH: Weinheim.

37. Javanshir, S.; Ohanian, A.; Heravi, M. M.; Naimi-Jamal, M. R.; Bamoharram, F. F. Ultrasound-promoted, rapid, green, one-pot synthesis of 2' -aminobenzothiazolomethylnaphthols via a multi-component reaction, catalyzed by heteropolyacid in aqueous media. (2011) Journal of Saudi Chemical Society, Accepted Manuscript (doi:10.1016/j.jscs.2011.10.013).

38. Ranu, B. C.; Banerjee, S. (2005) Ionic liquid as catalyst and reaction medium. the dramatic influence of a task-specific ionic liquid, [bmIm] OH, in Michael addition of active methylene compounds to conjugated ketones, carboxylic esters, and nitriles. Org. Lett., 7, 3049-3052.

39. Guo, K.; Thompson, M. J.; Chen, B. (2009) Exploring catalyst and solvent effects in the multicomponent synthesis of pyridine-3,5-dicarbonitriles. J. Org. Chem., 74, 6999-7006.

40. Dupont, J.; Consorti, C. S.; Suarez, P. A. Z.; De Souza, R. F. (2004) Preparation of 1-butyl-3-methyl imidazolium-based room temperature ionic liquids. Organic Syntheses, Coll.. 10, 184-187. 